\title{
Consultation with the Mind: The Power of Reflective Writing for Deepened Learning and Self-Knowledge in Teacher Education
}

\author{
MAUREEN P. HALL
}

"The second principle [of education] is that the mind has to be consulted in its own growth. The idea of hammering the child into the shape desired by the parent or the teacher is a barbarous and ignorant superstition. It is he himself who must be induced to expand in accordance with his own nature."

Sri Aurobindo, 1910, A System of National Education

Aurobindo's educational ideas resonate and have much relevance in today's complex educational arena. His second principle follows his first, which simply stated that "nothing can be taught." What Aurobindo means is that as teachers, all that we can do is provide quality learning opportunities for students. The work of learning requires an active partnership between teacher and student. Teaching is not just relaying information; teaching is not telling. A teacher cannot make a student learn. Here is where Aurobindo's second principle becomes very important. As teachers, we must help students find constructive ways to consult their own minds in the service of learning. And, as Aurobindo reminds us, this consultation with the mind must be done in accordance with one's "own nature."

\section{Reflective Writing Activates Students' Consultations with Mind}

How can a teacher help students to activate this consultation with their own minds and nature, as Aurobindo describes? This article describes how reflective writing can be used as a pedagogical tool or technique for improving learning in teacher education. Reflective writing can activate students' own learning processes and deepen learning.

I use reflective writing with my students, who are preservice and in-service teachers. Reflective writing is assigned both inside and outside class and both before and after I present new information and concepts to students. Through the reflective process, students actively consult with their minds, make connections between the new information and their prior experiences, and arrive at new understandings or insight that has the power to change them and their perspectives. Learning is just this--a change that occurs all the way to the cellular level and beyond. Inherent in this learning process or "consultation" with the mind, as Aurobindo outlines, is the student as the one who must make the learning happen. At the end of this paper, I will share pieces of my students' writings where they have articulated more specifically how reflective writing helps them learn.

\section{Contemplative Practice and Pedagogy}

Reflective writing can be a kind of contemplative practice. Contemplative Pedagogy refers to a range of practices that privilege and promotes the cultivation of students' (and faculty) attentional capacities. In Transforming Literacy, my recent book with Bob Waxler, we articulate many aspects of Contemplative Teaching and Learning:

Teachers who utilize contemplative practices connect with their students as whole persons, reaching their students on an emotional as well as on an intellectual level...We see such teaching as an embodied process, an adventurous journey that can facilitate the desired present moment and provide teaching and learning modes which are capacious enough to 
hold heart and mind, thoughts and feelings. (Waxler \& Hall, 2011, p. 100)

Contemplative Pedagogy and Practices hold great possibilities for deepening student learning. Many initiatives (partly informed by ancient wisdom traditions) call for renewed perspectives and practices on knowing and living in contemporary education.

Zajonc (2006), a contemplative practitioner and professor of physics articulates the changes needed in education:

I am calling for resituating it [education] within a greater vision of what knowing and living are really all about. That re-imagination of knowing will have deep consequences for education, consequences that give a prominent place to contemplative pedagogies...Such contemplative inquiry not only yields insight (veritas) but also transforms the knower through his or her intimate (one could say loving) participation in the subject of one's contemplative attention. Contemplative education is transformative education. (p. 1743)

In this passage, Zajonc emphasizes the importance of contemplative inquiry as a process of ongoing transformation and as a way of gaining both self-knowledge and knowledge of others. As teachers, we must constantly ask ourselves what is most important for students to learn. What does it mean to be an educated person? One of the most important goals of education is to develop the individual into a compassionate and kind human being. How can educational practices support this endeavor?

\section{Reflective Writing as Contemplative Practice}

Reflective writing has the potential to bring both the teacher and the learner to the present moment and manifest mindfulness. And, if we are to develop reflective writing as a new way to activate learning, we must begin to develop ways of measuring both the cognitive and affective dimensions of learning. First of all, it is important to point out that reflective writing can be a part of contemplative inquiry and pedagogy. In many ways, reflective writing combines elements of meditation and mindfulness, organically combining cognitive and affective dimensions of learning. Although Zajonc talks about the broader spectrum of contemplative inquiry, he does identify this inquiry as a way of coming to "insight" or deepened learning. Reflective writing can be a route to "insight" or deepened learning.

Siegel (2007) captures more specifically the affective benefits of what mindful awareness through written language, which can be viewed as synonymous for reflective writing, can bring about for the learner, who lives in the complexity of the modern world:

Words are the cognitive contraptions we use to work our way through the world of uncertainty. Words can free us: as symbols they are essential to distance us from experience enough to compare and contrast and reveal patterns in a complex universe. Seeing those patterns with ideas framed in our mind also enables us to communicate those insights to others. In these ways words are a wonderful gateway to understanding and sharing. (p. 160)

Writing can be a powerful tool for student learning. As Siegel points out, our use of words has the potential to deepen the learner's understanding of his or her experience, and words also have the capacity for conveying this learning to others.

\section{Metacognition}

Metacognition, or thinking about one's thinking, requires that learners see the same experience through different lenses: 
This process [metacognition] helps everyone to understand the commonality of human experience, how humans can share and build a sense of community, and to simultaneously appreciate the unique and individual meaning of those common experiences. It is a way of gaining and expanding knowledge in an imaginative learning space. (Waxler \& Hall, 2011, p. 60-61)

When a student understands this notion of metacognition by participating in a practice of it, he or she can reflect on ways (both successful and unsuccessful) for promoting learning. For a teacher, metacognition means thinking about what one is doing in the classroom, what the learning goals are of the activities, and making these dimensions transparent to one's students. I will share some examples of how I use reflective writing as formative assessment in my graduate teacher education courses. These examples may inspire and inform others in their thinking about how best to promote deepened learning and ways of using reflective writing to make this happen.

\section{Community}

Community, by definition, is where people come to count on others. The space of community in a classroom is where participants learn from each other. During my doctoral work at the University of Virginia, I became interested in the work of Parker Palmer because he valued approaches and parts of the teaching life that were overlooked. His was a voice that talked about important issues in teaching that others didn't even mention. In The Courage to Teach (1998), Palmer talked about fears teachers had as practitioners, how they could be connected or disconnected to the subject matter, their students and the teaching self. He tried to define community and how one goes about creating it in personal and public spaces of teaching and learning. My dissertation was 38 informed by Palmer's notions of community, and my research focused on how one teacher created a community of trust in a developmental writing classroom at the community college level. On some levels, I started to understand how important community was in my own life. It stood as sustenance that I sought in my life, in my own teaching and learning, and in both my personal and academic relationships with other people. And through contemplative practice on my own and in discourse with others, I work to create community in the teaching and learning spaces of which I am a member and facilitator.

More recently, my research in education has been connected to the Carnegie Foundation and involves looking more closely at the cognitive and affective dimensions of student learning and of reflective teaching. The terminology used in India for privileging cognitive affective learning includes "inner potentials" and "personality development." Certainly there are many different terms used, but the main point is that educators (or "educationists"--a term used in India) work to develop the whole person.

\section{The Importance of Reflection and Reflective Writing for Pre-service and In-Service Teachers}

An intense focus on only external or outer circumstances in students' and teachers' lives promote an incomplete vision of education, a place where opportunities are missed for developing inner potentials. Just as reflection on one's teaching represents a pathway for improving teaching and learning, the best teacher education programs must also promote, privilege, and practice the outer and inner life of the preservice teacher as he or she prepares for the classroom.

Teachers, both preservice and inservice, should work to develop and sustain the ability to reflect on their pedagogy as a part of the ongoing journey towards self-knowledge: 
Becoming more self-aware involves developing a reflexive capacity, although conceptualising the self from a 'selfcritical' position can lead to the new teacher internalising problems and leading to self-blame. (Demetrious \& Wilson, 2009, p. 216)

This capacity and practice of self-reflection should provide seeds for continual growth--not simply self-blame.

Although many teachers over time have been reflective about their teaching, the idea of one being a reflective practitioner was brought into the professional literature by Donald Schon in 1983. Long before Schon's work, John Dewey was espousing the idea of teachers' growth in terms of their abilities to be active decision-makers. Dale Frye articulates teacher educators' reflective goals for self and students:

It is our desire that our students become reflective practitioners - students who reflect on both the perspective of what it is like to be a learner and to be(come) a teacher... When teachers view themselves as learners, there is a sense of vulnerability that their students are able to sense; they are open and more perceptive to the subject(s) they are teaching and to students' needs. (p. 129)

Self-reflection has been emphasized through the ages. The ancient Greeks urge us: "know thyself." Socrates warned that an "unexamined" life lacks meaning; experience without reflection on that experience is meaningless. Active reflection is needed. The act of examining our lives as a "text" is a critical process, and learning how to be a critical thinker is certainly one part of being educated. Long before the Greeks made this urging, Ancient Indian wisdom called for the same self-knowledge. Ancient Indian texts, including the Vedas and the Upanishads, also contain kernels of wisdom that can be adapted and applied to the best education for teachers in the twenty-first century and beyond.

\section{Reflection in the Nursing Profession}

Marilyn Asselin, one of my colleagues in the Nursing program at the University of Massachusetts at Dartmouth, utilizes reflection and reflective writing to deepen her students' learning. She characterizes reflection as:

a deliberate and dynamic process of thinking about and clarifying the meaning of an experience within the context of one's existing knowledge, experience, and beliefs, thereby enabling one to gain insight into self and practice. (Asselin, 2011, p. 125)

Part of the beauty of this description has to do with its applicability across disciplines. Reflection and reflective practice is important in all disciplines. Both the fields of nursing and education involve professional licensure and require field experiences and reflection on those experiences.

\section{Teacher Education Students' Views on How Reflective Writing Promotes Their Learning From EDU 500}

In EDU 500 Fundamentals of Teaching and Learning, the very first course for teacher licensure, I utilize reflective writing assignments for scaffolding student learning in a few different ways. Two ways I utilize reflective writing as formative assessment include 1) helping students to develop a philosophy of teaching, and 2) for making meaning and documenting their prepracticum tutoring experiences through the creation of a case study of an urban K-12 student. One of my students in EDU 500, shared this reflection on reflective writing:

The benefits of reflective writing are vital to learning. The act of reflection 
enhances our understanding of any subject matter or experience. Reflective writing forces myself to write down what I know about something, and how and why this important. Instead of running a race of facts in my head, I am able to make connections to the facts that I am given. It gives the things I learn real world value, and enhances my understanding of the complex world around me. Furthermore, it forces me to look at what knowledge I am lacking and allows me to see what I need to gain more knowledge about. (Jessie Silvia, EDU 500, Fall 2012)

\section{From EDU 525}

Later in the licensure program, preservice teachers are required the capstone course for teacher licensure, which is called EDU 525 Integrated Reading Literacy and Content Methods. Thought there are no pre-practicum experiences connected to that course, I use reflective writing to scaffold classroom discussions and also for learning about essential concepts in the course. In preparation for this research, students read chapters on these concepts from Transforming Literacy (Waxler \& Hall, 2011) and construct weekly written reflections on these concepts. Nearer the end of that course, students find peer-reviewed sources to help deepen their understanding and articulation of these important concepts. Students construct research papers on one of two important concepts in the course; they can choose to investigate one of the following concepts in the course: "deep reading" or "contemplative practice." One student from EDU 525 shared this reflection on how she believes reflective writing promotes active learning:

Students are able to formulate their opinions, thoughts, and reactions to any subject before tendering them to the entire class. Students can focus on what others are saying when they've already had the opportunity to organize their thoughts, and each student, when asked to write, must actually think about the material. They cannot sit silent, hoping they will not be called, and let their opportunity to learn drift by like some apathetic barge on a river; no, they must be present. (Heather O'Donnell, Student in EDU 525, Fall, 2012).

Theorists and practitioners have shown that reflective written assignments may be more useful in making participants' cognitive processes explicit as they are formulating and taking in new ideas in order to actively construct knowledge about teaching and learning. In my work with preservice and inservice teachers, I promote written or narrative reflection after practical experiences. These reflective writing assignments connect or bind together in meaning the action and the learning possible from reflection on that action. (Hall, 2009)

Though teachers may not be able to make their students learn as Aurobindo points out, teachers can certainly provide students with good opportunities to be active participants in their own learning. Reflective writing offers one important pedagogical technique that can activate students' "consultation with their own minds." As teachers, we can promote and provide ways to help students' consultation with their own minds, and the result is improved and deepened student learning.

MAUREEN P. HALL, PhD, Associate Professor of Education, University of Massachusetts, Dart mouth, Massachusetts. 


\section{REFERENCES}

Asselin, M. E. (2011) Using reflection strategies to link course knowledge to clinical practice: The RN-to-BSN Student Experience. Journal of Nursing Education, 50(3), 125-133.

Aurobindo, S. (1910) A system of national education. Karmayogin: A weekly review. Pondicherry: Sri Aurobindo Ashram

Demetriou, H. \& Wilson, E. (2009) Synthesising affect and cognition in teaching and learning. Social Psychology of Education, 12(1), 213-232.

Hall, M. P. (2009) Service learning in urban alternative schools: Investigating affective development in preservice teacher education. Transformative Dialogues: Teaching and Learning Journal, 2 (3).
O'Donnell, H. (November, 2012) Personal Communication.

Siegel, D. J. (2007) The mindful brain: Reflection and attunement in the cultivation of well-being. New York, NY: W.W. Norton and Company.

Silva, J. (November, 2012) Personal Communication. Waxler, R.P. \& Hall, M.P. (2011) Transforming Literacy: Changing Lives Through Reading and Writing. England: Emerald Insight Publishing.

Zajonc, A. (2006) Love and knowledge: Recovering the heart of learning through contemplation. Teachers College Record, 108(9), 17421759. 